\title{
PERMINTAAN DAN PENAWARAN DALAM MEMPENGARUHI PASAR (Studi Kasus di Pasar Bintoro Demak)
}

\author{
Abdurrohman Kasdi \\ STAIN Kudus, Jl. Conge Ngembalrejo Kudus 59322 \\ abdurrohmankasdi@stainkudus.ac.id
}

\begin{abstract}
The market is the place to accommodate the results of the production and sell them to those in need. Islam set so that the competition in the market is done with fair, every form that can cause the injustice is forbidden by Islam. Reduce weights banned because of goods sold with the same price for the amount less. Hide the flawed goods forbidden, because the seller was getting a good for a bad quality. Changed the dried dates with palms wet forbidden, because the quantity of wet dates when dry can be so does not match with the dried dates that changed. For the community of Demak, Markets Bintoro is a parent market that has historical value. The market is known as the shopping center the results of earth City Mayor since colonial times. Various trade activities done at the site. Discounted Rates the results of the earth which is high enough in the place is the sale and purchase of staple food, especially rice. In the context of the request and the offer, kemanfaatanlah that move the demand in the market Bintoro Demak. If the benefit something very large, then the request will also be larger, so also on the contrary.
\end{abstract}

Key Words: Request, Price Offer Sharia Business

\section{A. Pendahuluan}

Permintaan dan penawaran merupakan dua aktivitas yang mendasari kegiatan perekonomian. Permintaan dan penawaran juga merupakan dua kata yang paling sering digunakan oleh para ekonom, keduanya merupakan kekuatan-kekuatan yang membuat perekonomian pasar bekerja. Sedangkan mekanisme pasar itu sendiri adalah interaksi yang terjadi antara permintaan (demand) dari sisi konsumen dan penawaran 
(supply) dari sisi produsen, sehingga harga yang diciptakan merupakan perpaduan dari kekuatan masing-masing pihak tersebut. Oleh karena itu, perilaku permintaan dan penawaran merupakan konsep dasar dari kegiatan bisnis.

Perbedaan prinsip antara permintaan dan penawaran dalam Islam dengan konfensional adalah terletak pada faktor utama dalam mempengaruhi permintaan dan penawaran. Menurut ekonomi konfensional titik beratnya pada harga, jika harga tinggi maka permintaan akan turun, begitu pula sebaliknya. Sedangkan dalam ekonomi Islam ini titikberatnya pada faedah, kemaslahatan ataupun manfaat suatu barang, sedangkan harga bukanlah tinjauan dasar dalam ekonomi Islam, tapi sisi religiuslah yang menjadi faktor utama. Dengan demikian, pandangan ekonomi Islam mengenai permintaan, penawaran dan mekanisme pasar ini relatif sama dengan ekonomi konvensional, namun terdapat batasan-batasan dari individu untuk berperilaku ekonomi yang sesuai dengan aturan syariah. Dalam ekonomi islam, norma dan moral Islami yang merupakan prinsip Islam dalam berekonomi, merupakan faktor yang menentukan suatu individu maupun masyarakat dalam melakukan kegiatan ekonominya.

\section{Prinsip Pasar dalam Perspektif Islam}

Urgensi pasar dalam Islam tidak lepas dari fungsi pasar sebagai wadah bagi berlangsungnya kegiatan jual beli. Pasar merupakan tempat bertemunya penjual dan pembeli dan melakukan transaksi barang atau jasa. Al-Ghazali dalam kitab Ihya' Ulumuddin menjelaskan tentang sebab timbulnya pasar "Dapat saja petani hidup di mana alat-alat pertanian tidak tersedia. Sebaliknya, pandai besi dan tukang kayu hidup di mana lahan pertanian tidak ada. Namun, secara alami mereka akan saling memenuhi kebutuhan masing-masing. Dapat saja terjadi tukang kayu membutuhkan makanan, tetapi petani tidak membutuhkan alat-alat tersebut. Keadaan ini menimbulkan masalah. Oleh karena itu, secara alami pula orang akan terdorong untuk menyediakan tempat penyimpanan alat-alat di satu pihak, dan penyimpanan hasil pertanian di pihak lain. Tempat inilah yang kemudian di datangi pembeli sesuai kebutuhannya masing-masing sehingga terbentuklah pasar. 


\section{Abdurrahman Kasdi}

Pasar dijamin kebebasannya dalam Islam. Hal ini menunjukkan bahwa pasar adalah tempat yang menampung hasil produksi dan menjualnya kepada mereka yang membutuhkan. Pernyataan tersebut juga menyebutkan bahwa pasar timbul dari adanya double coincidence yang sulit bertemu. Maka, untuk memudahkan adanya tukar-menukar dalam memenuhi kebutuhan diciptakanlah pasar. Pasar bebas menentukan cara-cara produksi dan harga, tidak boleh ada gangguan yang mengakibatkan rusaknya keseimbangan pasar.

Ada beberapa prinsip-prinsip mekanisme pasar Islam, yaitu: pertama, Ar-Ridha, yakni segala transaksi yang dilakukan haruslah atas dasar kerelaan antara masing-masing pihak. Hal ini sesuai dengan Qur'an Surat an Nisa' ayat 29: "Hai orangorang yang beriman, janganlah kamu saling memakan harta sesamamu dengan jalan yang batil, kecuali dengan jalan perniagaan yang berlaku dengan suka sama-suka di antara kamu. dan janganlah kamu membunuh dirimu; Sesungguhnya Allah adalah Maha Penyayang kepadamu." Kedua, Berdasarkan persaingan sehat. Mekanisme pasar akan terhambat bekerja jika terjadi penimbunan (ihtikar) atau monopoli. Monopoli dapat diartikan, setiap barang yang penahanannya akan membahayakan konsumen atau orang banyak. Ketiga, Kejujuran, Islam melarang tegas melakukan kebohongan dan penipuan dalam bentuk apapun. Sebab, nilai kebenaran ini akan berdampak langsung kepada para pihak yang melakukan transaksi dalam perdagangan dan masyarakat secara luas. Keempat, Keterbukaan serta keadilan, pelaksanaan prinsip ini adalah transaksi yang dilakukan dituntut untuk berlaku benar dalam pengungkapan kehendak dan keadaan yang sesungguhnya.

Islam mengatur agar persaingan di pasar dilakukan dengan adil, setiap bentuk yang dapat menimbulkan ketidakadilan itu dilarang yakni seperti: Talaqqi rukban, dilarang karena pedagang yang menyongsong di pinggir kota mendapat keuntungan dari ketidaktahuan penjual dari kampung akan harga yang berlaku di kota. Mengurangi timbangan dilarang, karena barang dijual dengan harga yang sama untuk jumlah yang lebih sedikit. Menyembunyikan barang yang cacat dilarang, karena penjual mendapat harga yang baik untuk kualitas yang buruk. Menukar kurma kering dengan kurma basah dilarang, karena takaran kurma basah ketika kering bisa 
jadi tidak sama dengan kurma kering yang ditukar. Menukar satu takar kurma kualitas bagus dengan dua takar kurma kualitas sedang dilarang, karena kualitas kurma mempunyai harga pasarnya.

\section{Permintaan dan Penawaran dalam Islam}

Permintaan (demand) adalah banyaknya jumlah barang yang diminta pada suatu pasar tertentu dengan tingkat harga tertentu pada tingkat pendapatan tertentu dan dalam periode tertentu (Putong, 2002: 33). Permintaan dalam Islam tentunya memperhatikan syariat yang mengajarkan bahwa kita tidak boleh serakah dan mengeksploitasi sesuatu secara berlebihan, karena akan berdampak buruk kepada kita, dan Allah SWT pun senantiasa tidak menyukai orang-orang yang berlebihan. Pilihan seorang Muslim dalam hal permintaan dibangun atas kebutuhan akan mashlahah, baik mashlahah yang diterima di dunia ataupun di akhirat.

Ajaran Islam mengharuskan orang untuk mengkonsumsi barang yang halal dan baik. Aturan islam melarang seorang muslim memakan barang yang haram, kecuali dalam keadaan darurat dimana apabila barang tersebut tidak dimakan, maka akan berpengaruh terhadap nya muslim tersebut. Di saat darurat seorang muslim dibolehkan mengkonsumsi barang haram secukupnya. Dalam ajaran Islam, orang yang mempunyai uang banyak tidak serta merta diperbolehkan untuk membelanjakan uangnya untuk membeli apa saja dan dalam jumlah berapapun yang diinginkannya. Batasan anggaran belum cukup dalam membatasi konsumsi. Batasan lain yang harus diperhatikan adalah bahwa seorang muslim tidak berlebihan (israf), dan harus mengutamakan kebaikan (maslahah). Islam tidak menganjurkan permintaan terhadap suatu barang dengan tujuan kemegahan, kemewahan dan kemubadziran.

Permintaan dalam Islam menilai suatu komoditas tidak semuanya bisa dikonsumsi maupun digunakan, masih perlu dibedakan antara yang halal dan yang haram. Allah telah berfirman: "Hai orang-orang yang beriman, janganlah kamu haramkan apa - apa yang baik yang telah Allah halalkan bagi kamu, dan janganlah kamu melampaui batas. Sesungguhnya Allah tidak menyukai orang - orang yang melampaui batas. Dan makanlah 
makanan yang halal lagi baik dari apa yang Allah telah rezekikan kepadamu, dan bertakwalah kepada Allah yang kamu beriman kepadaNya." (QS. Al-Maidah: 87 - 88)

Sehingga dalam teori permintaan Islami membahas permintaan barang halal, barang haram, dan hubungan antara keduanya. Sedangkan dalam permintaan konvensional, semua komoditi dinilai sama, bisa dikonsumsi atau digunakan. Permintaan Islam bertujuan mendapatkan kesejahteraan atau kemenangan dunia juga akhirat, dan akhirat (falah) sebagai turunan dari keyakinan bahwa ada kehidupan yang abadi setelah kematian yaitu kehidupan akhirat setelah meninggalkan dunia, sehingga anggaran yang ada harus disisihkan sebagai bekal untuk kehidupan akhirat.

Menurut Ibnu Taimiyah (1263-1328) sebagaimana dikutip oleh Abdul Azhim Islahi, adanya keinginan terhadap sesuatu (raghabat fi al-syai) merupakan salah satu faktor pertimbangan dari permintaan. Harga barang yang diminta, tingkat pendapatan, jumlah penduduk, selera dan perkiraan (spekulasi) harga barang di masa yang akan datang, dan harga barang lain atau barang substitusi sangat mempengaruhi adanya permintaan. Besar kecilnya perubahan permintaan ditentukan oleh besar kecilnya perubahan harga. Jika ini terjadi, maka berlaku perbandingan terbalik antara harga terhadap permintaan dan berbanding lurus dengan penawaran.

Seirama dengan hal itu, Ibnu Khaldun menyatakan apabila suatu daerah mempunyai kota yang luas dan penduduknya banyak, maka harga kebutuhan murah dan harga barang mewah menjadi mahal. Tidak dapat diragukan bahwa penduduk kota memiliki makanan lebih dari kebutuhan mereka. Akibatnya, harga makanan sering murah. Selanjutnya, bila suatu kota telah makmur, padat penduduknya, penuh dengan kemewahan, maka akan muncul kebutuhan yang besar akan barang-barang mewah, sehingga barang mewah akan semakin mahal harganya (Ibu Khaldun, 1983: 421).

Sedangkan Penawaran adalah barang atau jasa yang ditawarkan pada jumlah dan tingkat harga tertentu dan dalam kondisi tertentu. Dalam beberapa hal, ada yang membedakan antara penawaran Islam dengan penawaran hedonis, bahwa barang atau jasa yang ditawarkan harus transparan dan dirinci spesifikasinya, bagaimana keadaan barang tersebut, apa 
kelebihan dan kekurangan barang tersebut. Jangan sampai penawaran yang dilakukan merugikan pihak yang mengajukan permintaan. Adapun Rasulullah dalam melakukan penawaran selalu merinci tentang spesifikasi barang dagangannya.

Dalam konteks ini, teori penawaran merupakan teori yang menerangkan sifat penjual dalam menawarkan barang yang akan dijual. Gerakan sepanjang dan pergeseran kurva penawaran perubahan dalam jumlah yang ditawarkan dapat berlaku sebagai akibat dari pergeseran kurva penawaran. Dengan kata lain definisi penawaran bisa juga dijelaskan dengan proses pada umumnya, sumber dan teknik produksi yang digunakan oleh seorang produsen dapat digunakan untuk memproduksi berbagai macam dan jumlah yang diproduksi.

\section{B. Pembahasan}

\section{Sejarah Kawasan Pasar Bintoro Demak}

Hari jadi Kabupaten Demak ditetapkan pada tanggal 28 Maret 1503. Menurut Tim Peneliti Sejarah berdirinya kota Demak, Raden Patah dinobatkan sebagai sultan Demak pada tanggal 12 Robiul Awal tahun Caka 1425 (28 Maret 1503 M), sehingga setiap tanggal tersebut selalu diperingati sebagai hari jadi kota Demak. Peringatan ini menjadi momentum bagi masyarakat Demak untuk mengembalikan kejayaannya. Tentu bukan kejayaan dalam artian menjadikan daerah kerajaan, melainkan spirit yang mendorong kemajuan daerah hingga kesejahteraan rakyat meningkat (Abdurrahman Kasdi, 2010: 5).

Dalam buku Babat Tanah Jawi, tempat yang bernama Demak berawal dari Raden Patah diperintahkan oleh gurunya (Sunan Ampel) agar merantau ke Barat dan bermukim di sebuah tempat yang terlindung hutan/tanaman Gelagah Wangi letaknya berada di Muara Sungai Tuntang yang sumbernya berada di lereng Gunung Merbabu (Rawa Pening). Hingga sekarang ini Nama Bintoro masih di kenal dengan nama suatu desa di daerah Demak. Namun dahulunya nama Bintoro adalah nama Kota Demak itu sendiri pada zaman Kasultanan Sultan Fatah.berdasarkan keterangan dari juru kunci makam Sentoro Ratu Kauman Demak Bapak Syamsuri (alm), bahwa nama Bintoro di ambil dari nama pohon Bintaro yang dahulu pernah tumbuh di sekitar Hutan Glagah Wangi (Hasanu Simon, 2005: 75). 


\section{Abdurrahman Kasdi}

Menurut Prof. Soetjipto Wirjosoeprapto, setelah hutan Gelagah Wangi ditebang dan didirikan tetrukan (pemukiman), baru muncul nama Bintoro yang berasal dari kata bethoro (bukit suci bagi penganut agama hindu). Pada kawasan yang berada di sekitar muara Sungai Tuntang, bukit sucinya adalah Gunung Bethoro (Prawoto) yang sekarang masuk daerah Kabupaten Pati. Menurut beberapa sumber lain menyebutkan bahwa nama bintoro diambil dari nama pohon Bintoro yang dulu banyak tumbuh di sekitar hutan Gelagah Wangi. Ciri-ciri pohon Bintoro mulai dari batang, daun, dan bunganya mirip dengan pohon kamboja (apocynaceae sp.), hanya saja buahnya agak menonjol seperti buah apel.

\section{Renovasi Pasar Bintoro Demak}

Bagi masyarakat Demak, Pasar Bintoro merupakan pasar induk yang memiliki nilai sejarah. Pasar itu sudah dikenal sebagai pusat perbelanjaan hasil bumi Kota Wali sejak zaman penjajahan Belanda. Berbagai kegiatan perdagangan dilakukan di tempat tersebut. Transaksi hasil bumi yang cukup tinggi di tempat itu adalah jual-beli sembako, terutama beras. Namun seiring perjalanan waktu perdagangan beras bergeser ke tempat penggilingan padi dan pasar pun beralih untuk perdagangan sembako dan kelontong.

Menurut Penasehat Paguyuban Pedagang Pasar Bintoro (P4B) yang juga mantan Wakil Bupati H Muhammad Asyiq, bangunan asli atau bangunan induk berada di tengah pasar. Pada tahun 1962, lanjut dia, dilakukan pengembangan sayap pasar berupa penambahan bangunan untuk kios dan ruko. Bangunan baru itu menutupi bangunan induk sehingga tidak terlihat ciri khas bangunan lamanya. Perjalanan waktu kemudian tumbuh los-los tidak permanen mengelilingi bangunan pasar. Bahkan, saat itu mulai terdapat pedagang liar di sepanjang jalan masuk. Hal itu membuat pasar menjadi kumuh (Wawancara Drs H Muhammad Asyiq, 15 Oktober 2016)

Secara keseluruhan pasar memiliki 2.500 tempat (los dan kios) yang dimiliki sekitar 1.700 pedagang. Karena kekumuhannya itu, pada 2004 ada rencana merenovasi secara total bangunan pasar tersebut. Namun rencana itu mendapat reaksi dari pedagang. Ketua Paguyuban Pedagang Pasar 
Bintoro (P3B) H Muntaqo pernah memprotes pemkab karena ketidaktegasan pemerintah dalam melakukan penataan pedagang ilegal (Wawancara Drs H Muntaqo, 19 Oktober 2016). Rencana penolakan terhadap renovasi itu memunculkan kekhawatiran pedagang, jika sewaktu-waktu ada sabotase berupa pembakaran pasar. Kekhawatiran itu bukan tanpa alasan, sebab di beberapa daerah yang pasar yang terbakar, biasanya terjadi karena akan dilakukan renovasi. Mereka kemudian membuat jadwal untuk berjaga malam dan iuran membayar penjaga malam.

Pasar tersebut sudah kali ketiga ini terbakar. Namun dalam dua peristiwa sebelumnya, amukan si jago merah dapat dijinakan. Kerugian material tidak terlalu besar. Pertama, kebakaran terjadi 1993. Peristiwa terjadi sekitar pukul 18.30 atau sesudah shalat Maghrib. Kendati tidak besar, terdapat beberapa ruko di tengah pasar yang hangus. Kedua, tahun 2004 menimpa dua kios warung. Peristiwa itu pun terjadi pada malam hari. Hanya saja sebelum api membesar, berhasil dijinakan oleh petugas jaga malam bersama petugas pemadam kebakaran. Yang ketiga, kebakaran besar seperti ini terjadi pada tahun 2006 sampai menghangsukan sebagian besar barang dagangan.

Dilihat dari tata letaknya, lokasi pasar yang sekarang memiliki 2.500 tempat dagang berupa ruko, kios dan los ini sangat stretegis karena berada di tengah kota. Di sebelah utara terdapat Sungai Jajar yang tidak pernah kekeringan air. Karena itu dia merasa heran, pasar sebesar Bintoro bisa habis terbakar. Nur Haryono, seorang warga sekitar merasa prihatin atas terbakarnya pasar itu. Hemat dia, terbakarnya pasar hingga ludes dirasakan tidak masuk akal. Betapa tidak, pasar ada di tengah kota, di samping pasar ada sungai yang airnya mengalir dan banyak orang berlalu lalang, kok bisa sampai terbakar ludes (Wawancara Nur Haryono, 21 Oktober 2016).

Untuk itu dia meminta kepada aparat kepolisian agar mengusut kasus itu secara tuntas. Dia menduga ada upaya secara sistematis dari pihak-pihak tertentu untuk kepentingan pribadi. Ketika muncul isu pasar akan direnovasi masa pemerintahan sebelumnya, muncul penolakan dari pedagang. Hal itu mengakibatkan suasana pasar menjadi memanas. 
Sepakat, para pedagang melakukan pengamanan dengan menggunakan beberapa orang sipil.

Seiring sukses kepemimpinan Bupati beberapa waktu silam, isu renovasi itu mereda. Pengamanan pasar dari pihak sipil pun mulai longgar. Bahkan, sekitar sebulan lalu pengamanan itu sudah tidak dilakukan lagi. Mau tidak mau dengan adanya kebakaran tersebut, pemkab Demak melakukan renovasi pasar yang sekarang tampak megah.

\section{Pasar Bintoro sebagai Penopang Sektor Ekonomi Demak}

Pasar Bintoro terletak di Jalan Sultan Fatah, Bintoro, Demak, Bintoro, Kec. Demak, Kabupaten Demak, Jawa Tengah 59511. Pasar Bintoro nan megah yang posisinya berada di antara dua obyek wisata religi andalan Kota Wali, diharapkan mampu menopang sektor ekonomi Demak. Karena itulah, beberapa kios di pasar yang berlokasi relatif dekat dengan Masjid Agung Demak (MAD) dan tidak pula terlalu jauh dari Makam Sunan Kalijaga di Kadilangu itu sengaja dijadikan showroom sekaligus sentra penjualan berbagai produk khas berkearifan lokal dan produk asli Demak.

Menurut Kabag Humas Setda Rudi Santosa SH, karena diproyeksikan menjadi jujugan mencari oleh-oleh bagi para wisatawan, pemkab memberikan fasilitasi kepada Dewan Kerajinan Nasional Daerah (Dekranasda) dan TP PKK Kabupaten Demak untuk berperan serta memamerkan produkproduk unggulan khas Kota Wali. Pemkab pun menyediakan tempat pamer dan sentra oleh-oleh di lantai dasar Pasar Bintoro yang diperkirakan paling strategis. Kios tersebut cukup mudah dijangkau oleh pengunjung. Maklum, lokasinya tak jauh dari parkiran dan berada di deretan paling depan. Kios untuk Dekranasda ada 2 unit, dan satu kios lagi dipercayakan kepada TP PKK Kabupaten Demak (Wawancara Rudi Santosa SH, 12 Agustus 2016).

Dua kios yang dikelola Dekranasda posisinya bersebelahan. Satu kios untuk memamerkan dan menjual produk-produk makanan olahan. Sedangkan satunya lagi diperuntukan produk kerajinan non olahan, seperti kain bordir, batik, kerudung, handycraft, kaligrafi, T Shirt, sepatu, sandal dan lain sebagainya. Adapun TP PKK Kabupaten Demak memasarkan berbagai produk yang dihasilkan para kadernya. 
Sejauh ini cukup banyak produk Demak yang telah memperoleh pangsa pasar di tingkat lokal maupun nasional. Di antaranya celana dalam produk Desa Cabean, sanggul buatan perajin Desa Geneng Mijen, batik tulis Karangmlati, bordir khas Desa Pasir Mijen, kerudung 'made in' Jungsemi, serta kain tenun buatan perajin Desa Tedunan Kecamatan Wedung. Selain kualitasnya yang dinilai mampu bersaing, harga produk itu juga cukup terjangkau.

Banyak pula produk makanan olahan produksi warga Demak yang kini telah memiliki pangsa pasar tetap. Antara lain terasi buatan perajin Morodemak Kecamatan Bonang, ikan asap khas Wonosari, bandeng presto buatan perajin Sayung, kerupuk tayamum asli Ngaluran, telur asin dari Desa Kenduren Wedung dan Loireng Sayung, serta onde-onde asli Desa Pulosari Karangtengah. Dengan memberi kesempatan kepada Dekranasda dan TP PKK kabupaten, berarti pemkab turut membantu para pelaku UMKM dalam melakukan pemasaran.

Langkah demikian sekaligus untuk menumbuhkan kreatifitas warga Demak, serta menggerakkan roda perekonomian yang diyakini akan memberikan dampak terhadap meningkatnya kesejahteraan masyarakat. Keberadaan Pasar Bintoro memang sangat strategis. Selain dapat menggerakkan geliat UMKM dan menopang kemajuan pariwisata, pasar dengan pedagang yang jumlahnya mencapai ribuan tentu juga berpotensi meringankan beban pemerintah dalam menekan angka kemiskinan. Pasalnya, aktifitas yang berlangsung di lingkungan pasar sepanjang hari terbukti mampu menyerap banyak tenaga kerja.

Hal senada diungkapkan Kepala Dinas Pariwisata dan Kebudayaan Kabupaten Demak, Drs M Ridwan. Ia menyampaikan, Masjid Agung Demak (MAD) dan Makam Sunan Kalijaga yang merupakan mahakarya wali sembilan itu setiap tahunnya dikunjungi jutaan wisatawan. Keberadaan MAD berikut dengan benda-benda bersejarah di sekelilingnya, tradisi budaya, serta makam Sunan Kalijaga dan berbagai peninggalannya, tentu saja merupakan aset yang tak ternilai. Semua itu diyakini tetap akan menjadi daya tarik sampai kapanpun. Sebisa mungkin kita harus mampu memikat jutaan pengunjung agar sudi membelanjakan uangnya di Kota Wali. 


\section{Abdurrahman Kasdi}

Salah satu caranya adalah dengan menyediakan oleh-oleh baik berupa barang maupun makanan yang harganya terjangkau namun berkualitas prima. Selebihnya juga perlu adanya lokasi belanja yang representatif. Saya memprediksi, Pasar Bintoro akan mampu menjawab tantangan itu asalkan pengelolaannya dilakukan secara profesional (Wawancara Drs M Ridwan, 12 Agustus 2016).

Keberadaan MAD dan Makam Sunan Kalijaga berpotensi menarik minat kalangan investor untuk turut berperan dalam pengembangan pariwisata Demak. Apalagi, Kabupaten Demak kini memiliki pasar megah nan nyaman yang berlokasi tak jauh dari kedua obyek andalan itu. Adapun peluang investasi menyangkut sektor pariwisata cukup mungkin diwujudkan dalam berbagai bentuk usaha, misalnya saja bisnis perhotelan juga biro perjalanan wisata.

Sedangkan terkait soal pengelolaan, Masrukin, Kepala UPTD Pasar I menambahkan, untuk memberikan citra positif kepada para wisatawan maka pihaknya akan mencurahkan perhatian lebih terhadap hal-hal yang berkaitan dengan kebersihan, keamanan dan kenyamanan. Menyangkut itu semua, tanggungjawab diserahkannya kepada enam orang petugas santib juga para tenaga kebersihan. Tenaga kebersihan selalu mobil. Kalau dulu sampah hanya dibersihkan pada jamjam tertentu, kemudian petugas menyapu pasar cuma di pagi dan sore hari. Sekarang tidak lagi seperti itu. Tak perlu menunggu hingga menumpuk, pokoknya ada sampah ya langsung mereka pungut (Wawancara Masrukin, 12 Agustus 2016).

\section{Hal-hal yang Mempengaruhi Permintaan dan Penawaran di Pasar Bintoro}

Permintaan terjadi, menurut Ibnu Taimiyah ini karena dipengaruhi beberapa hal: pertama, Keinginan atau selera masyarakat terhadap suatu barang yang berbeda daan selalu berubah-ubah. Dimana ketika masyarakat telah memiliki selera terhadap suatu barang maka hal ini akan mempengaruhi jumlah permintaan terhadap barang tersebut. Kedua, Jumlah para peminat terhadap suatu barang. Jika jumlah masyarakat yang menginginkan barang tersebut semakin banyak, maka harga barang tersebut akan semakin meningkat. Ketiga, Kualitas 
pembeli (al-mu'awid). Dimana tingkat pendapatan merupakan salah satu cirri kualitas pembeli yang baik. Semakin besar tingkat pendapatan, semakin tinggi kualitas manyarakat untuk membeli. Keempat, Lemah atau kuatnya kebutuhan suatu barang. Apabila kebutuhan terhadap suatu barang itu tinggi maka permintan terhadap barang itu juga tinggi. Kelima, cara pembayaran (tunai atau angsuran). Jika pembelian barang tersebut dengan transaksi tunai, biasanya permintaannya lebih tinggi. Dan keenam, Besarnya biaya transaksi. Apabila biaya transaksi dari suatu barang rendah, maka permintaan akan meningkat (Islahi, 1988: 92-93).

Sedangkan menurut menurut pedagang pasar Bintoro Demak, permintaan dipengaruhi oleh beberapa hal: pertama, perilaku konsumen (selera konsumen). Saat ini suatu produk sedang trend dan banyak yang beli, tetapi beberapa tahun mendatang mungkin produk tersebut sudah dianggap kuno. Kedua, Ketersediaan dan harga barang sejenis pengganti dan pelengkap. Jika roti tawar tidak ada atau harganya sangat mahal maka meises, selai dan margarin akan turun permintaannya. Ketiga, Pendapatan (penghasilan) konsumen. Orang yang punya gaji dan tunjangan besar dia dapat membeli banyak barang yang dia inginkan, tetapi jika pendapatannya rendah maka seseorang mungkin akan mengirit pemakaian barang yang dibelinya agar jarang beli. Keempat, Perkiraan harga di masa depan, Barang yang harganya diperkirakan akan naik, maka orang akan menimbun atau membeli ketika harganya masih rendah misalnya seperti bbm/bensin. Kelima. Intensitas kebutuhan konsumen, Ketika flu burung dan flu babi sedang menggila, produk masker pelindung akan sangat laris. Pada bulan puasa (ramadhan) permintaan belewah, timun suri, cincau, sirup, es batu, kurma, dan lain sebagainya akan sangat tinggi dibandingkan bulan lainnya.

Selanjutnya, permintaan seseorang terhadap barang menurut pandangan pedagang ditentukan oleh: pertama, harga barang itu sendiri dan harga barang substitusi, misalnya gula dan kopi. Bila permintaan terhadap kopi meningkat, maka permintaan terhadap gula juga meningkat, demikian sebaliknya. Kedua, pendapatan rumah tangga dan pendapatan rata-rata masyarakat. Ketiga, corak distribusi pendapatan dan cita rasa masyarakat. Keempat, jumlah penduduk, 
bertambahnya jumlah penduduk akan menambah permintaan berbagai barang. Kelima, ramalan mengenai keadaan masa depan (Sukirno, 2002: 75).

Adapun faktor yang mempengaruhi penawaran, menurut Ibnu Khaldun adalah banyaknya permintaan tingkat keuntungan relative (tingkat harga), tingkat usaha manusia (produktifitas) misalnya besarnya tenaga buruh termasuk termasuk ilmu pengetahuan yang dimiliki dan keterampilan yang dimiliki, keamanan dan ketenangan serta kemampuan teknik dan perkembangan secara keseluruhan dari suatu kegiatan bisnis. Faktor yang lain yang mempengaruhi penawaran terhadap suatu barang adalah: pertama, biaya dan teknologi. Biaya dan teknologi adalah dua konsep yang sangat erat berkaitan satu sama lain. Yang dimaksud dengan biaya adalah biaya yang dikeluarkan untuk memproduksi barang dan jasa mencakup baiaya tenaga kerja, biaya bahan baku, jika sistem ekonomi konvensional dalam dalam operasionalnya. Teknologi adalah penemuan dan peningkatan teknologi yang diterapkan untuk menurunkan biaya produksi contohnya adalah penggunaan robot dan komputer. Jika diterapkan teknologi baru dan sebagainya.

Kedua, Jumlah penjual. Jumlah penjual memiliki dampak langsung terhadap penawaran makin banyak jumlah penjual yang mampu menjual pada tingkat harga tertentu makin tinggi penawaran. Ketiga, dugaan tentang masa depan. Aspek dugaan atau ekspetasi teerhadap masa depan mencakup dugaan mengenai perubahan harga dari barang tersebut. Misalnya, jika penjual menduga bahwa harga barangnya akan meningkat dimasa depan, ia akan mengurangi penawarannya pada saat ini. Akibatnya penawarannya berkurang. Hal ini dilarang oleh nabi, karena seperti nanti yang akan kita lihat, perilaku ini mengakibatkan harga dipasar melonjak. Keempat, Kondisi alam. Kondisi alam seperti terjadi banjir, gempa bumi dan sebagainya. Bisa mengakibatkan penawaran barang-barang tertentu berkurang seperti barang-barang hasil pertanian dan lain sebagainya.

\section{Pengendali Harga di Pasar Bintoro Demak}

Islam tidak membenarkan penahanan barang yang dilakukan untuk tujuan spekulasi seperti menimbun barang 
ketika harga barang rendah sehingga menyebabkan barang itu langka, dengan tujuan dapat menjualnya ketika harga naik karena ingin meraih keuntungan semata. Hal ini termasuk ihtikar yang tidak diperbolehkan dalam mempengaruhi harga.

Dalam konteks pengendalian harga, Ibnu Khaldun ternyata merumuskan teori harga jauh sebelum ekonom Barat modern merumuskannya. Sebagaimana disebut di awal, Ibnu Khaldun telah mendahului Adam Smith, Keyneys, Ricardo dan Malthus. Inilah fakta sejarah yang tak terbantahkan. Menurut Ibnu Khaldun yang mengendalikan harga adalah penawaran dan permintaan. Jadi bilamana permintaan meningkat, maka hargapun akan meningkat pula. Sebaliknya bilamana permintaan menurun, harga pun akan menurun.

Dalam hal ini kemanfaatanlah yang menggerakkan permintaan di pasar Bintoro Demak. Jika kemanfaatan sesuatu sangat besar, maka permintaan juga akan semakin besar, demikian pula sebaliknya. Ibnu Khaldun membedakan antara kebutuhan primer dan sekunder, dan ia membedakan antara pasar kota-kota yang banyak penduduknya dan pasar-pasar yang sedikit penduduknya, dari segi penerapan hukum penawaran dan permintaan. Pada bagian lain dari bukunya, Ibn Khaldun menjelaskan pengaruh naik dan turunnya penawaran terhadap harga. Ia mengatakan bahwa ketika baarang-barang yang tersedia sedikit, maka harga-harga akan naik. Namun bila jarak antarkota dekat dan aman untuk melakukan perjalanan, maka akan banyak barang yang diimpor sehingga harga-harga akan turun karena ketersediaan barang melimpah.

\section{Simpulan}

Hubungan antara harga dengan jumlah permintaan ini berlaku untuk hampir semua barang dalam transaksi di pasar Bintoro Demak, dan dalam kenyataannya, para pedagang dimana pun menyebut hal ini sebagai hukum permintaan. Jika hal-hal lain tetap, ketika suatu barang naik jumlah permintaan untuk barang tersebut akan turun. Sebaliknya, ketika harganya turun jumlah permintaan naik. Sedangkan Hukum penawaran menerangkan apabila harga sesuatu barang meningkat, kuantitas barang ditawar akan meningkat dan apabila harga sesuatu barang menurun, kuantitas barang yang ditawar akan 
menurun. Hukum ini menunjukkan wujud hubungan positif antara tingkat harga dan kuantitas barang yang ditawar. Hal ini disebabkan karena harga yang tinggi member keuntungan yang lebih kepada produsen, jadi produsen akan menawarkan lebih banyak barang. Harga yang tinggi menyebakan produsen berpendapat barang tersebut sangat diminta oleh konsumen tetapi penawarannya kurang di pasaran. Produsen akan menambahkan penawaran untuk memenuhi permintaan. 
Permintaan dan Penawaran dalam Mempengaruhi Pasar

\section{Daftar Pustaka}

Ibnu Khaldun. 1983. Abdurrahman al-Maghriby, Muqaddimah, Dâr al-Qalam, Beirut Libanon, cet ke-5.

Islahi, Abdul Adzim, (1988). Economic Concep of Ibn Taimiyah, London: The Islamic Foundation.

Mulyana, Slamet. 2005. Runtuhnya Kerajaan Hindu-Jawa dan Timbulnya Negara-Negara Islam di Nusantara, Jogjakarta: PT. LkiS Pelangi Aksara.

Putong, Iskandar. 2002. Ekonomi Mikro dan Makro, Jakarta: Ghalia Indonesia.

Saksono, Widji. 1996. Mengislamkan Tanah Jawa; Telaah atas Metode Dakwah Walisongo, Bandung: Mizan, Cet. 3.

Simon, Hasanu, Misteri Syekh Siti Jenar: Peran Walisongo dalam Mengislamkan Tanah Jawa, Yogyakarta: Pustaka Pelajar, cet. II.

Sukirno, Sadono. .2002. Pengantar Teori Mikro Ekonomi, Jakarta: PT Raja Grafindo Persada.

Wawancara dengan Drs H Muhammad Asyiq pada tanggal 15 Oktober 2016 di rumahnya.

Wawancara dengan Drs H Muntaqo pada tanggal 19 Oktober 2016 di rumahnya.

Wawancara dengan Nur Haryono pada tanggal 21 Oktober 2016 di rumahnya.

Wawancara dengan Rudi Santosa SH pada tanggal 12 Agustus 2016 di rumahnya.

Wawancara dengan Drs M Ridwan pada tanggal 12 Agustus 2016 di rumahnya. 


\section{Abdurrahman Kasdi}

Wawancara dengan Masrukin pada tanggal 12 Agustus 2016 di rumahnya.

http:/ / www.suaramerdeka.com/v1/index.php/read/cetak/2 010/03/30/103875/Memetakan-Empat-Potensi-Demak, diunduh pada 12 Oktober 2016.

http:/ / www.suaramerdeka.com/v1/index.php/read/cetak/2 013/03/19/218874/Mendorong-Demak-Setara, diunduh pada 12 Oktober 2016.

http:/ / berita.suaramerdeka.com/smcetak/demak-serambimadinah, diunduh pada 12 Oktober 2016. 